\title{
PENGARUH MODEL CIRC (COOPERATIVE INTEGRATED READING AND COMPOSITION) DENGAN MENGGUNAKAN PETA KONSEP TERHADAP HASIL BELAJAR SISWA PADA MATERI JARINGAN TUMBUHAN DI KELAS XI IPA SMA MUHAMMADIYAH 1 MEDAN
}

\author{
Chantria Novita Syaputri ${ }^{*}$, Ely Djulia \\ Program Studi Pendidikan Biologi, Fakultas Matematika dan IPA, Universitas Negeri Medan \\ Jl. William Iskandar Pasar V Medan Estate, Medan, Indonesia \\ Email : chantria.novita@gmail.com
}

\begin{abstract}
ABSTRAK
Penelitian ini bertujuan untuk mengetahui pengaruh model pembelajaran CIRC dengan Peta Konsep terhadap hasil belajar siswa pada materi Jaringan Tumbuhan di kelas XI IPA SMA Muhammadiyah 1 Medan T.P.2017/2018. Jenis penelitian ini adalah eksperimen semu (quasi experiment)dengan populasi penelitian seluruh kelas XI IPA SMA Muhammadiyah 1 Medan terdiri dari 2 kelas. Sampel penelitian ini dipilih dengan menggunakan teknik Total Sampling. Instrumen yang digunakan dalam penelitian ini adalah tes dalam bentuk objektif tes, yaitu sebanyak 25 soal yang masing-masing telah dinyatakan valid dan reliabel. Berdasarkan uji persyaratan data diketahui bahwa data hasil penelitian berdistribusi normal dan kedua kelas memiliki kesamaan varians (homogen). Dari analisis data diketahui bahwa nilai rata-rata postes siswa yang diajar dengan CIRC adalah 84,12 dan nilai rata-rata postes siswa yang diajar dengan CIRC menggunakan peta konsep adalah 90,06 . Ada perbedaan yang signifikan terhadap hasil belajar siswa, ini dibuktikan melalui uji-t pada taraf signifikan $\alpha=0,05$ dan dk 62 diperoleh $t_{\text {hitung }}>t_{\text {tabel }}(3,079>1,999)$ maka penelitian ini menolak Ho dan menerima Ha. Dengan demikian, dapat disimpulkan bahwa terdapat pengaruh hasil belajar siswa yang diajarkan dengan model pembelajaran CIRC dengan menggunakan Peta Konsep pada materi Jaringan Tumbuhan Di Kelas XI IPA SMA Muhammadiyah 1 Medan T.P. 2017/2018.
\end{abstract}

Kata Kunci: CIRC, CIRC dengan menggunakan Peta Konsep, Hasil Belajar.

\section{ABSTRACT}

This study aims to determine the effect of CIRC learning model with concept map on student learning outcomes on plant tissue material in class XI IPA SMA Muhammadiyah 1 Medan T.P.2017 / 2018. This research type is quasi experiment with research population of all class XI IPA SMA Muhammadiyah 1 Medan consists of 2 classes. The sample of this research is selected by using technique of Total Sampling. The instrument used in this study is the test in the form of objective tests, which are as many as 25 questions that each have been declared valid and reliable. Based on the data requirement test, it is known that the research data is normally distributed and the two classes have the same variance (homogeneous). From the data analysis it is known that the mean score of postes of students who were taught with CIRC was 84.12 and the mean score of postes of students who were taught with CIRC using concept map was 90.06. There is a significant difference on student learning outcomes, it is proved by t-test at significant level $\alpha=0,05$ and $d k 62$ obtained $t_{\text {count }}>t_{\text {table }}$ (3,079> $1,999)$ hence this research reject $\mathrm{Ho}$ and accept $\mathrm{Ha}$. Thus, it can be concluded that there is influence of student learning outcomes taught by CIRC learning model using Concept Map on Plant Network material In Class XI IPA SMA Muhammadiyah 1 Medan T.P. 2017/2018.

Keywords: CIRC, CIRCusing concept map, the results of the study.

\section{PENDAHULUAN}

Jaringan tumbuhan adalah kumpulan sel-sel tumbuhan yang memiliki struktur dan fungsi sama. Dalam materi jaringan tumbuhan terdapat kompetensi dasar yang harus dicapai dalam pembelajaran yaitu mengidentifikasi struktur jaringan tumbuhan dan mengaitkan dengan fungsinya, dan menjelaskan sifat totipotensi sebagai dasar kultur jaringan. Sehingga, untuk mencapai suatu kompetensi dasar tersebut diperlukan suatu model pembelajaran yang dapat meningkatkan pemahaman siswa.

Berdasarkan hasil wawancara dengan guru biologi di kelas XI IPA di SMA Muhammadiyah 1 Medan, bahwa sejauh ini pembelajaran biologi yang dilakukan di dalam kelas masih bersifat konvensional yaitu masih menggunakan model ceramah yang kadang disertai tanya jawab. Hal ini berarti pembelajaran biologi masih berpusat pada guru (teacher centered), sehingga siswa kurang 
terlibat secara aktif dalam proses belajar. Namun demikian, pada saat proses pembelajaran guru terkadang menjelaskan materi dengan menayangkan video pembelajaran menyangkut materi jaringan tumbuhan. Hal ini, siswa dapat lebih aktif dan mudah untuk menjelaskan sifat totipotensi sebagai dasar kultur jaringan.

Materi jaringan tumbuhan merupakan materi yang banyak melakukan praktikum. Hal ini dikarenakan, materi jaringan tumbuhan sangat bersifat ilmiah. Dalam proses pembelajaran, guru memberikan praktikum kepada siswa hanya sekali atau dua kali dalam sub materi pelajaran biologi. Namun, dikarenakan di sekolah SMA Muhammadiyah 1 Medan sedang melakukan renovasi laboratorium. Sehingga, siswa tidak mampu mengidentifikasi struktur jaringan dan organ pada tumbuhan dan mengaitkan dengan fungsinya. Maka untuk itu kurangnya pengetahuan siswa dalam dunia tumbuhan sehingga guru hanya mampu memberikan ringkasan kepada siswa.

Dalam pembelajaran biologi mencatat adalah hal yang paling penting. Hal ini, karena catatan dapat membantu siswa untuk mengingat dan mengulas kembali apa yang telah dipelajarinya. Pada saat mencatat, siswa cenderung memakai teknik mencatat biasa dan kebanyakan siswa membuat kalimat yang panjang sehingga membutuhkan waktu yang lama untuk mengingatnya kembali. Padahalnya catatan berguna untuk mempermudahkan kita dalam menghafal suatu materi. Selain itu, catatan akan terlihat bagus jika bervariasi seperti adanya gambar, bagan dan hiasan warna. Sehingga, siswa mampu memberikan pemahaman dan daya ingat yang maksimal tentang suatu konsep pada materi jaringan tumbuhan. Berdasarkan hal demikian dapat digunakan suatu teknik mencatat, diantaranya adalah teknik Concept Map.

Dilihat dari pencapaian hasil belajar siswa kelas XI IPA mengenai materi jaringan tumbuhan, hasil belajar siswa masih tergolong rendah yakni 60 $\%$ siswa masih mencapai nilai 60 dan tidak memenuhi Kriteria Ketuntasan Minimal (KKM) $\geq$ 75 , sehingga siswa masih perlu dilakukan remedial agar nilai siswa menjadi lebih baik. Dari hasil belajar siswa dikatakan minim dikarenakan tidak tuntasnya siswa dalam mengidentifikasi struktur dan fungsi jaringan serta organ pada tumbuhan.
Hal ini siswa diharapkan agar dapat memahami lebih dalam lagi mengenai jaringan tumbuhan. Dalam upaya meningkatkan hasil belajar siswa, maka diperlukan model pembelajaran yang dapat memperbaiki kualitas pembelajaran di kelas, sehingga prestasi belajar siswa dapat meningkat dan kompetensi dasar tercapai.

Upaya meningkatkan hasil belajar siswa dalam materi jaringan tumbuhan dapat dibantu dengan menerapkan model pembelajaran kooperatif yang dapat diterapkan oleh guru adalah CIRC (Irawati T, 2011). Cooperative Integrated Reading and Composition (CIRC) adalah salah satu model cooperative learning yang telah berhasil diterapkan dan dapat mengaktifkan siswa dalam belajar dengan teman sekelompoknya yang terdiri atas 4-5 siswa. Dalam kelompok ini sebaiknya ada siswa yang pandai, sedang atau lemah, dan masing-masing siswa merasa cocok satu sama lainnya. Dengan pembelajaran kooperatif ini diharapkan siswa membangun kemampuan untuk membaca dan mampu mengerjakan soal-soal berbentuk wacana agar meningkatkan cara berfikir kritis, kreatif dan menumbuhkan rasa sosial yang tinggi pada saat pembelajaran di kelas.

Selain menerapkan model pembelajaran kooperatif sebagai upaya untuk meningkatkan hasil belajar siswa diperlukan juga sebuah media pembelajaran (Arsyad, A, 2009). Untuk melengkapi model pembelajaran $C I R C$ dapat digunakan media pembelajaran berupa peta konsep. Peta konsep digunakan sebagai teknik pencatatan siswa yang lebih menarik dan mampu membantu siswa dalam mengingat materi jaringan tumbuhan dengan mudah (Munthe, B, 2009). Selain itu berdasarkan penelitian yang didapatkan bahwa peta konsep sebagai alat pembelajaran yang menggunakan pengingat-pengingat visual dan sensorik yang sesuai dengan cara kerja otak seperti gambar, simbol, dan warna (Hartantio Y, 2014). Dalam hal mengaplikasikan keterampilan yang dimiliki siswa dalam suatu kegiatan ilmiah yang akhirnya membuat siswa dapat menemukan pengetahuan baru, perlu diterapkan model pembelajaran yang menarik untuk peserta didik dan disini guru berfungsi sebagai fasilitator (Hasruddin, 2016).

Berdasarkan latar belakang permasalahan diatas, peneliti tertarik untuk melakukan penelitian dengan judul "Pengaruh Model CIRC (Cooperative 
Integrated Reading and Composition) Dengan Menggunakan Peta Konsep Terhadap Hasil Belajar Siswa Pada Materi Jaringan Tumbuhan Di Kelas XI IPA SMA Muhammadiyah 1 Medan T.P 2017/2018".

\section{METODE PENELITIAN}

Jenis penelitian ini adalah penelitian eksperimen semu (Quasi Eksperiment) yang melibatkan dua kelas eksperimen. Penelitian ini didesain dengan melakukan pretes dan postes. Perlakuan pembelajaran kelompok I diajar dengan model pembelajaran CIRC dengan Peta Konsep dan kelompok II diajar dengan model pembelajaran CIRC. Untuk memudahkan penelitian yang akan dilaksanakan maka perlu dibuat desain pada Tabel 1 berikut ini.

Tabel 1. Rancangan Pembelajaran

\begin{tabular}{cccc}
\hline Kelompok & Pre Test & Perlakukan & Post Test \\
\hline I & $\mathrm{T}_{1}$ & $\left(\mathrm{X}_{1}\right)$ & $\mathrm{T}_{2}$ \\
II & $\mathrm{T}_{1}$ & $\left(\mathrm{X}_{2}\right)$ & $\mathrm{T}_{2}$ \\
\hline
\end{tabular}

\footnotetext{
Keterangan:

T1 : Pretest yang diberikan pada kelompok I dan kelompok II

T2:Post test yang diberikan pada kelompok I dan kelompok II

X1:Perlakuan yang diberikan pada kelompok I (CIRC dengan peta konsep)

X2:Perlakuan yang diberikan pada kelompok II (CIRC)
}

Penelitian dilaksanakan di SMA

Muhammadiyah 1 Medan pada semester ganjil 2017/2018. Populasi penelitian disini adalah seluruh siswa kelas XI SMA Muhammadiyah 1 Medan. Sampel yang digunakan menggunakan model Total Sampling berarti keseluruhan siswasiswi kelas XI IPA SMA Muhammadiyah 1 Medan (Sugiyono, 2015). Variabel dalam penelitian ini ada dua adalah (1).Variabel bebas yaitu model pembelajaran CIRC dengan peta konsep, Model Pembelajaran CIRC. Sedangkan (2).Variabel terikat yaitu hasil belajar siswa pada materi jaringan tumbuhan.

Berdasarkan desain penelitian yang dirancang maka langkah penelitian yang dilakukan adalah sebagai berikut: (1). Tahap persiapan (2). Tahap pelaksanaan (3). Tahap analisis data (Sudijono,A, 2011). Instrumen pengambilan data meliputi penilaian kognitif. Teknik analisis instrumen kognitif menggunakan (Arikunto,S, 2011) : (1). Uji validitas, Adapun jumlah tes yang diuji cobakan adalah sebanyak 40 soal. Dari hasil uji coba yang dilakukan diperoleh sebanyak 30 soal yang valid, 10 soal yang dinyatakan tidak valid. Soal yang valid tersebut kemudian dijadikan alat pengumpul data. Soal yang digunakan dalam penelitian ini adalah 25 soal yang diambil dari soal- soal yang telah valid. (2). Uji reliabilitas, instrumen dinyatakan reliabel sebab harga reliabilitas sebesar 0,797 . (3). Tingkat kesukaran, diperoleh bahwa dari 40 soal ada 7 soal dengan tingkat kesukaran "mudah" atau 17,5 \% , 25 soal memiliki tingkat kesukaran "sedang" atau 62,5\% dan 8 soal dengan tingkat kesukaran "sukar" atau $20 \%$. (4). Daya pembeda tes, diperoleh bahwa dari 40 soal ada 19 soal memiliki daya beda "cukup" atau 47,5 $\%$, dan 8 soal memiliki daya beda "baik" atau $20 \%$ dan 13 soal memiliki daya beda "jelek" atau 32,5\%.

Teknik analisis data yang digunakan adalah uji t-pihak kanan yang mensyaratkan data normal dan homogen, untuk menguji apakah sampel penelitian distribusi normal atau homogen. Setelah itu digunakan rumus t-test dengan polled varians dan uji N-Gain.

\section{HASIL PENELITIAN}

Data yang diperoleh dalam penelitian ini adalah hasil belajar siswa pada materi jaringan tumbuhan yang meliputi aspek kognitif.Data penelitian mengenai hasil belajar secara ringkas disajikan pada Tabel 2.

Tabel 2. Rangkuman Data Penelitian

\begin{tabular}{lcc}
\hline \multirow{2}{*}{ Jenis Penelitian } & \multicolumn{2}{c}{ Nilai Rata-Rata } \\
\cline { 2 - 3 } & Eksp I & Eksp II \\
\hline Pretest & 47,39 & 90,06 \\
Postest & 44,38 & 84,12 \\
\hline
\end{tabular}


Berdasarkan Tabel 2 terlihat bahwa nilai kognitif pada kelas eksperimen I (model pembelajaran CIRC dengan Peta Konsep) lebih tinggi dibandingkan kelas eksperimen II (mode pembelajaran $C I R C$ ). Hasil perhitungan uji N-Gain dalam Tabel 3. Dan perhitungan uji t-pihak kanan dalam Tabel 4 pretes dan Tabel 5 postes.

Tabel 3. Perhitungan N-Gain Hasil belajar

\begin{tabular}{|c|c|c|c|c|c|c|c|}
\hline \multirow{2}{*}{ Kelas } & \multirow{2}{*}{$\mathbf{N}$} & \multicolumn{2}{|c|}{ Nilai $(\bar{x})$} & \multirow{2}{*}{$\begin{array}{l}\text { Postes- } \\
\text { Pretes }\end{array}$} & \multirow[b]{2}{*}{ Selisih } & \multirow[b]{2}{*}{ Gain } & \multirow[b]{2}{*}{ \%Gain } \\
\hline & & Pretes & Postes & & & & \\
\hline CIRC + Peta Konsep & 33 & 47,39 & 90,06 & 42,67 & 52,60 & 0,763 & 76,33 \\
\hline CIRC & 31 & 44,38 & 84,12 & 39,74 & 55,61 & 0,718 & 71,88 \\
\hline
\end{tabular}

Tabel 4. Perhitungan uji t prestes

\begin{tabular}{|c|c|c|c|c|}
\hline Sampel & Rata-rata & $t_{\text {hitung }}$ & $t_{\text {tabel }}$ & Kesimpulan \\
\hline Kelas CIRC + peta konsep & 47,39 & & & Tidak Berbeda \\
\hline Kelas CIRC & 44,38 & 1,33 & 1,999 & Signifikan \\
\hline
\end{tabular}

Tabel 5. Perhitungan uji t postest

\begin{tabular}{lcccc}
\hline \multicolumn{1}{c}{ Sampel } & Rata-rata & $\mathbf{t}_{\text {hitung }}$ & $\mathbf{t}_{\text {tabel }}$ & Kesimpulan \\
\hline Kelas CIRC +_peta konsep & 90,06 & \multirow{2}{*}{3,079} & \multirow{2}{*}{1,999} & Berbeda \\
Kelas CIRC & 84,12 & & & Signifikan \\
\hline
\end{tabular}

Berdasarkan data yang dilakukan diatas, hasil perhitungan uji N-Gain pada Tabel 3 diperoleh peningkatan hasil belajar siswa di kelas yang diajar dengan model pembelajaran CIRC dengan Peta Konsep sebesar 0,7633 atau 76,33\% dan kelas yang diajar dengan CIRC sebesar 0,7188 atau $71,88 \%$. Peningkatan hasil belajar dari kedua kelas tersebut memiliki kategori tinggi ( $\mathrm{g}>0,7$ ). Sedangkan dari hasil uji t-pihak kanan pada Tabel 4 pretest diperoleh $t_{\text {hitung }}=1,33$ lebih kecil dari $t_{\text {tabel }}$ $=1,999$

dengan taraf signifikan $5 \%$, maka $\mathrm{H}_{0}$ diterima $\mathrm{Ha}$ ditolak berarti tidak ada pengaruh model pembelajaran CIRC menggunakan Peta Konsep dengan CIRC terhadap hasil belajar siswa pada materi jaringan tumbuhan di kelas XI-IPA SMA Muhammadiyah 1 Medan Tahun Pembelajaran 2017/2018. Dan perhitungan uji tpostest pada Tabel 5 diperoleh $t_{\text {hitung }}=3,079$ lebih besar dari $t_{\text {tabel }}=1,999$ dengan taraf signifikan $5 \%$, maka $\mathrm{H}_{0}$ ditolak dan $\mathrm{Ha}$ diterima berarti ada pengaruh model pembelajaran CIRC menggunakan Peta Konsep terhadap hasil belajar siswa pada materi jaringan tumbuhan di kelas XI-IPA SMA Muhammadiyah 1 Medan Tahun Pembelajaran 2017/2018.
Berdasarkan nilai peta konsep siswa (Novak and Gowin, 1985) pada kelas CIRC dengan peta konsep diperoleh nilai rata-rata proposisi (P) adalah 30,74 , pada hirarki $(H)$ sebesar 17,58 , pada kaitan silang (KS) sebesar 25,80, contoh (C) sebesar 0,67 dan nilai rata-rata skor total (ST) adalah 74,80 . Maka penafsiran presentase dari rata-rata skor total memiliki predikat baik. Untuk lebih jelas lihatlah diagram 1 berikut ini.

Dari pengamatan peneliti selama melaksanakan penelitian, kegiatan pembelajaran yang dilakukan di kelas yang diajar menggunakan model CIRC dengan peta konsep berlangsung dengan baik. Hal ini ditunjukkan dari sikap siswa antara lain :(1) Para siswa masih aktif dalam bertanya mengenai materi jaringan tumbuhan, (2) Pada saat diskusi para siswa mampu bekerja sama dengan baik bersama anggotanya untuk mempelajari materi jaringan tumbuhan dan mengerjakan soal diskusi yang tertera di LKS.(3) Banyaknya siswa yang bertanya dan ingin tahu mengenai LKS dan Wacana yang diberikan oleh guru, (4) Banyaknya siswa yang bertanya dan ingin tahu mengenai peta konsep, (5) Para siswa terlihat senang dalam pembelajaran terutama saat prosesmembuat peta konsep, karena mereka dapat bebas mengeluarkan ide dan kreatifitasnya, 
(6) Para siswa terlihat sudah paham dan hafal apa yang meraka tulis pada peta konsep yang dibuat oleh mereka sendiri. Hal ini dapat terjadi karena mereka membuat peta konsep berdasarkan peta konsep acuan dan kreativitas mereka sendiri dan menggunakan warna yang memudahkan mereka untuk mengingat materi jaringan tumbuhan, (7) Prestasi belajar siswa pada aspek kognitif juga meningkat.

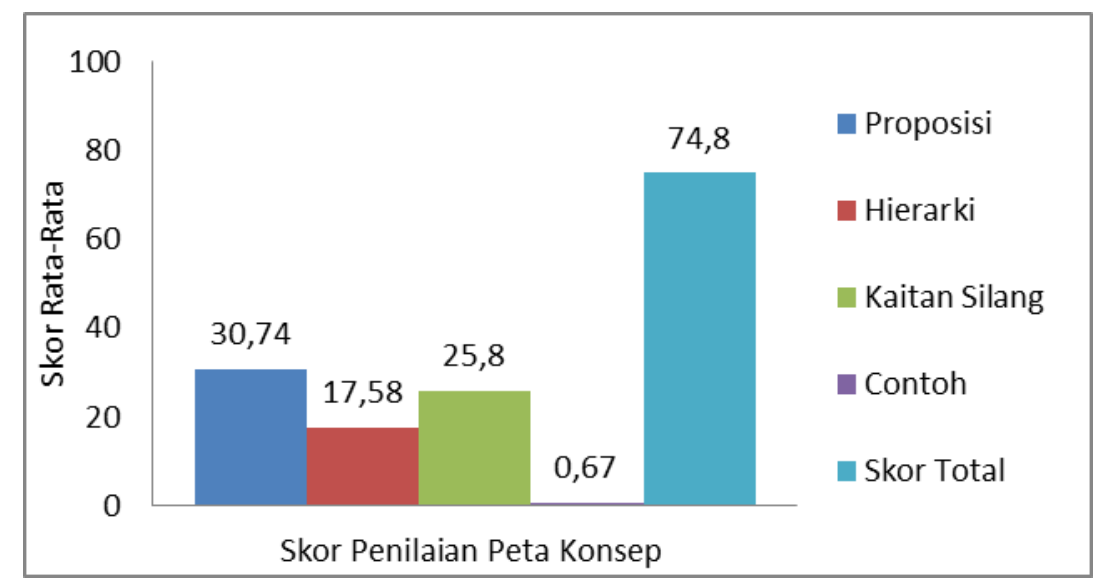

Gambar 1. Penilaian Peta Konsep

Pada kelas yang diberikan pengajaran dengan model pembelajaran CIRC meskipun terlihat antusias dalam belajar kebanyakan siswa masih terkesan individual. Hal ini ditunjukkan dari sikap siswa antara lain : (1) Banyaknya siswa yang masih pasif dalam mengikuti kegiatan proses belajar mengenai materi jaringan tumbuhan. (2) Pada saat diskusi, siswa lebih mementingkan diri sendiri daripada tim kelompoknya, (3) Para siswa juga terkesan ingin menang sendiri untuk mendapatkan nilai yang baik pada saat mengerjakan LKS yang telah diberikan oleh guru. (4) Pada saat presentasi yang terdiri dari 4-5 siswa, hanya 1-2 siswa saja yang memaparkan presentasi dengan baik dan sebagian siswa hanya diam tanpa sepengetahuan apapun. Sehingga hal ini siswasiswi tersebut tidak memperoleh informasi yang utuh mengenai materi jaringan tumbuhan yang telah diajarkan.

Melihat dari kondisi kedua kelas eksperimen ini menunjukkan bahwa kelas yang diajar menggunakan model CIRC dengan peta konsep mempunyai motivasi dan rasa ingin tahu yang tinggi daripada kelas yang diajar menggunakan model CIRC (Sadiman,A, 2005),. Hasil penelitian tersebut dapat terjadi karena peta konsep adalah cara termudah untuk menempatkan informasi ke dalam otak dan mengambil informasi ke luar dari otak. Peta konsep juga merupakan cara mencatat yang kreatif, efektif, dan secara harfiah akan memetakan suatu konsep dari materi yang diajarkan. Peta konsep juga sangat sederhana. Selain itu, peta konsep dapat membantu kita dalam mengingat banyak hal seperti merencana, berkomunikasi, menjadi lebih kreatif, menghemat waktu, menyelesaikan masalah, memusatkan perhatian, menyusun dan menjelaskan, mengingat dengan lebih baik dan belajar lebih cepat dan efisien.

Hasil penelitian ini memperkuat teori Gestalt yang mendukung belajar sebagai proses mengembangkan insight. Insight adalah pemahaman terhadap hubungan antarbagian di dalam suatu situasi permasalahan.Teori Gestalt termasuk pada aliran kognitif holistik yang dikembangkan oleh Koffka, Kohler dan Wertheimer. Berbeda dengan teori behavioristik yang menganggap belajar atau tingkah laku itu bersifat mekanistis, sehingga mengabaikan atau mengingkari peranan insight. Teori Gestalt justru menganggap bahwa insight adalah inti dari pembentukan tingkah laku (Sanjaya, 2006).

\section{KESIMPULAN}

Berdasarkan hasil penelitian maka dapat disimpulkan bahwa adanya pengaruh model pembelajaran CIRC dengan Peta Konsep terhadap hasil belajar siswa (dengan $\mathrm{N}$-gain $76,33 \%$ ) pada 
materi Jaringan Tumbuhan di kelas XI IPA SMA Muhammadiyah 1 Medan tahun pembelajaran 2017/2018.

Berdasarkan penelitian ini, maka peneliti memberikan saran untuk perbaikan antara lain: (1).Bagi guru-guru biologi agar menggunakan model pembelajaran CIRC dengan Peta Konsep pada materi jaringan tumbuhan supaya siswa tidak jenuh, dan lebih aktif dalam proses pembelajaran. (2).Bagi mahasiswa yang ingin mengembangkan penelitian CIRC dengan peta konsep sebaiknya kegiatan peta konsep dilakukan di kegiatan student creative. (3).Bagi peneliti lain yang ingin mengembangkan penelitian CIRC dengan peta konsep sebaiknya kegiatan pada tahap team scorer and recognition diperlukan teknik khusus agar kelompok siswa dapat berpresentasi. (4).Peta konsep dalam penelitian ini berupa teknik pencatatan siswa. Maka sebaiknya guru menggunakan peta konsep dalam pembelajaran pada materi Jaringan Tumbuhan agar siswa mampu memahami materi tersebut dengan mudah.

\section{DAFTAR PUSTAKA}

Arikunto, S, (2011), Dasar-Dasar Evaluasi Pendidikan (Edisi Revisi), PT Bumi Aksara, Jakarta.

Arsyad, A, (2009), Media Pembelajaran, Rajawali, Jakarta.

Hartantio Y, (2014), Penerapan Strategi Belajar Peta Konsep Untuk Meningkatkan Hasil Belajar Siswa Pada Standar Kompetensi Menerapkan Dasar-Dasar Elektronika Digital Di SMKN 1 Driyorejo, Jurnal Pendidikan Teknik Elektro. Vol 03,133-140.

Hasruddin, (2016), Pengaruh Pembelajaran Berbasis Masalah Dan Penemuan Terbimbing Terhadap Keterampilan Proses Sains Siswa SMA Negeri 1 Langsa. Jurnal Pendidikan Biologi. Vol. 6.,No.1.

Irawati T, (2011), Pengaruh Pembelajaran Cooperative Integrated Reading And Composition (CIRC) Berbantuan Scramble Terhadap Hasil Belajar Kognitif Materi Sistem Peredaran Darah Siswa SMP. Semarang, Universitas Negeri Semarang, Skripsi.

Munthe, B, (2009), Desain Pembelajaran, PT Pustaka Insan Madani, Yogyakarta.
Novak and Gowin, (1985), Learning how to learn, Cambridge; Cambridge University Press.

Sadiman, A,S, (2005), Media pendidikan, PT Raja Grafindo, Jakarta.

Sanjaya,W, (2006), Strategi Pembelajaran Berorientasi Standar Proses Pendidikan, Prenada Media Group, Jakarta.

Sudjana, (2001), Metoda Statistika, Tarsito, Bandung.

Sudijono,A, (2011), Pengantar Evaluasi Pendidikan, Rajawali, Jakarta.

Sugiyono, (2015),Metode Penelitian Pendidikan, Penerbit Alfabeta, Bandung. 